the villages to talk to the people in their own localities. The reports, he said very accurately described the spray planes, the effects of the herbicides on the vegetation, and the accountants of the toxic effects on humans were consistent from village to village. The report itself says that "reports of illness following spraying are so striking it is difficult to dismiss them as simply the effects of propaganda, high normal death rates, or faulty understanding of cause and effect".

Asked why the reports of death came mostly from the highland people, Hickey suggested a number of possible reasons. First, they were hit mostly with agent orange, perhaps the most toxic of the herbicides used in the military operations, particularly since it is contaminated with TCDD. Second, the defoliation missions wiped out their crops because their fields are mostly in areas of reclaimed forest, and this tended to increase exposure to the chemicals. Third, the Montagnards tend to live out of doors much more than the lowlanders do, and they carry their children on their backs when they work in the fields. Thus they would be more likely to be exposed to the herbicide sprays. And finally, the people repeatedly emphasised in their interviews that they "didn't know what was happening" when the aircraft started spraying, and many of the children drank contaminated water or ate sprayed crops.

Since the reports came from direct interviews with Montagnards, they are difficult to verify by independent means, but Dr Hickey, a world renowned authority on the Montagnard people, is extremely disturbed by them. He is also extremely disturbed by Dr Handler's personal introduction to the academy report, which labelled the accounts as "secondhand" and "tales". Handler also said that the committee regrets that it was unable to visit the Montagnards in their own regions to verify the reports. Hickey did, however, get his information firsthand (albeit with the help of interpreters), and he did follow up his investigations in the Montagnard villages. He said last week that he had no chance to see Handler's introduction, in fact he didn't even know it would be written, and said that he finds it "outrageous". He said that in his nine years in Vietnam, he has encountered innumerable attempts at covering up the damage wrought by the war, and that this "is another one of them".

As for the effects of herbicides on birth defects and stillbirths, the report explicitly states that the team "could find no conclusive evidence of association between exposure to herbicides and birth defects in humans". The basis for that comment was a search through the records of two major Saigon hospitals which showed "no consistent pattern of association between rates of congenital malformations and annual amounts of herbicides sprayed".

But a more extensive study is being conducted on the records of the Childrens Medical Relief International unit (the so-called Barsky Unit) of the Cho Ray Hospital in Saigon-Cholon. The study is not yet completed, but the report says that so far there is no strong evidence for an association between herbicides and birth defects.

Two members of an earlier survey of the effects of herbicides in Vietnam, the AAAS study, said last week, however, that the team had not conducted as thorough a study as it could, and suggested that a follow-up is required. Dr John Constable, of Harvard Medical School and Massachusetts General Hospital, suggested that the academy team had failed to look more closely at the figures from the Saigon Children's Hospital, particularly in the years following the AAAS study. "They reexamined our figures", he said, "but they have not attempted to add figures of their own".

The AAAS study pointed out that incidence of cleft lip, relative to other birth defects in the records of the Saigon Children's hospital, showed a marked increase in the years 1966-1968, the years of heaviest herbicide spraying. Although the AAAS team, which was led by Meselson, was careful to say that this effect was not necessarily correlated with herbicide spraying, the figures at least bear close scrutiny. The fact that the academy team had not looked at data from the hospital in the years after 1970 is, according to Meselson, "disappointing".

If there is a teratogenic effect from herbicide spraying, it is likely to have come from the TCDD contamination in the agent orange. TCDD-which is often more familiarly referred to as dioxin--is an extremely potent teratogen in mice, and when it was discovered in 1970 that it is always present in 2,4,5-T, there was great consternation about the risks to Vietnamese people exposed to agent orange. The chemical is such a potent teratogen that it is feared that amounts too small to be detected may prove to be harmful if they get into the food supply.

Last year, however, Meselson and his colleague Robert T. Baughman, reported an extremely sensitive method for detecting TCDD, which they used to analyse fish samples taken from South Vietnam in 1970 . They found levels of the chemical ranging from 0.0007 parts per million to 0.008 parts per million. They are now in the process of analysing fish and shrimp samples taken last year, and preliminary results indicate that there is still some contamination with TCDD. The academy committee considered these findings to be "a matter which warrants further attention". Use of Meselson's method for detecting dioxin in the food supply would be an ideal basis for selecting populations to study for birth defects.

Although the academy's study will clearly spark off a considerable debate about the conclusions that have been drawn, there is no doubt that it has added a huge amount of information on one of the most contentious issues to arise from the Vietnam war. In fact the report published last week was only a summary of the data (even though it ran to 400 pages), and the academy intends to publish later this year all the documentation gathered together during the three years that the report was in preparation.

It remains to be seen whether this wealth of information is sufficient to build up a strong enough case to convince the Administration that herbicides should be banned from use in war. The United States has yet to ratify the Geneva protocol of 1925 which outlaws the use in war of chemical weapons. Ratification of the treaty is now being held up because the US Senate insists that the protocol covers herbicides and tear gases, while the Administration insists that it doesn't. Secretary of State Henry Kissinger informed the Senate Foreign Relations Committee last year that the Administration's position is under review. The academy study is likely to play a considerable role in that review.

\section{Unfilled places}

MORE than six thousand university places, mainly in science, engineering and technology subjects, went unfilled in Britain at the beginning of the current academic year. The figures are contained in the eleventh report of the Universities Central Council on Admissions (UCCA), the body which handles the applications of most intending students in Britain. According to UCCA, the British universities expected to receive 71,875 students in October last year, and in fact only 65,586 places were taken. The shortfall in engineering and technology was 1,991 , and in science 3,198 . In a foreword to the report, Chairman of the Council Dr Geoffrey Templeman says that although the figures contain an element of estimation, and therefore need to be used with care, the picture they reveal is "not encouraging". 